\title{
SDG-1 and 5 Complemented by BNF at Bangladesh: An Investigation
}

\author{
Muhammad Mahboob Ali ${ }^{1}$, Md. Kamrul Hossain ${ }^{2}$, ABM Alauddin Chowdhury ${ }^{3}$, \\ Alexandru Nedelea ${ }^{4}$ \\ ${ }^{1}$ Department of Economics and Entrepreneurship, Dhaka School of Economics Bangladesh, Dhaka, Bangladesh \\ ${ }^{2}$ Department of Natural Sciences, Daffodil International University (DIU), Dhaka, Bangladesh \\ ${ }^{3}$ Department of Public Health, Daffodil International University, Dhaka, Bangladesh \\ ${ }^{4}$ Department of Economics, Business Administration and Tourism, Stefan cel Mare University of Suceava, Suceava, Romania
}

Email address:

pipulbd@gmail.com (M. M. Ali), Kamrul.ns@diu.edu.bd (Md. K. Hossain), dralauddin@daffodilvarsity.edu.bd (ABM A. Chowdhury), alexandrun@seap.usv.ro (A. Nedelea)

\section{To cite this article:}

Muhammad Mahboob Ali, Md. Kamrul Hossain, ABM Alauddin Chowdhury, Alexandru Nedelea. SDG-1 and 5 Complemented by BNF at Bangladesh: An Investigation. International Journal of Statistical Distributions and Applications. Vol. 3, No. 4, 2017, pp. 113-123. doi: $10.11648 /$ j.jijsd.20170304.18

Received: July 3, 2017; Accepted: August 25, 2017; Published: November 30, 2017

\begin{abstract}
The Government of the People's Republic of Bangladesh has established Bangladesh NGO Foundation (BNF) to support the NGOs, with a view to associate the Non-Governmental Organizations and assigned to take up socio- economic development activities and poverty alleviation. The country has also been facing massive challenges of feeding the rapidly increasing population or even to support their livelihood in a sustainable manner. Bangladesh NGO foundation already disbursed more than 110 Crore taka through partner organizations out of which $36 \%$ is male while $64 \%$ is female beneficiary. The study intends to see whether SDG 1 and 5 is implementing through BNF or not. Time period of the study was 15 May 2016 to 30th June, 2017. This study aimed to find out whether sustainable development goal 1 and 5 of BNF partner organization due to BNF grant is indicating any significant role? Research question of the study is whether BNF's partner organizations sustainable development goal 1 and 5 of BNF partner organization due to BNF grant? Self-administered questionnaires were used to collect the data for this study. NGOs are working for women's entrepreneurship since expanding women's economic opportunities is fundamental to sustainable growth and building more equitable societies. In this study, $93.9 \%$ of the organizations give help to women entrepreneurs. Majority $(69.6 \%)$ of the respondents were strongly agreed that BNF's financing and capital formatting solve social problem. It has been seen that there was significant association between NGOs role for removing poverty and fulfilling towards SDG1 and 5 as disparity of removing inequality of poor women group has been also occurring. Equitable justice and removing income inequality is occurring through BNF grant. However, restructuring of $\mathrm{BNF}$ is required as it lacks any vision, mission and marketing approach as well as supply chain management process. BNF also need to take a project to play as a financial intermediary to ensure community banking in Bangladesh under separate regulator.
\end{abstract}

Keywords: BNF, Beneficiaries, Socio-economic Development, Relation to Social Values, Sustainability, Income, Welfare and Poverty Reduction, Non-farm Business Activities, Finance in Rural Economies, Community Banking

\section{Introduction}

Sustainability of an organization is pursuing to device sustainability strategies which deliver them with economic and cultural benefits attained through social obligations.
Sustainability of an organization must have adoption capability, creativeness, human welfare, service delivery, profit growth and competitive advantage. The Government of 
the People's Republic of Bangladesh has established Bangladesh NGO Foundation (BNF) to support the NGOs, with a view to associate the Non-Governmental Organizations and mandated to take up socio- economic development activities and poverty alleviation initiatives through NGOs. BNF was established through a Resolution of the Government on 02 December 2004 that was published in the Bangladesh Gazette on 11 December 2004. The FOUNDATION was then registered a non-profit association within the meaning of Section 28 of the Companies Act, 1994. Rauschmayer et al. (2011) argued that sustainable development is development that meets the needs of the present without compromising the ability of future generations to meet their own needs. It contains within it two key concepts: the concept of "needs", in particular the essential needs of the world's poor to which overriding priority should be given;and the idea of limitations imposed by the state of technology and social obligation on the environment's ability to meet the present and future needs as described by Rauschmayer et al.(2011) from WCED 1987. When the World Commission on Environment and Development (Brundtland Commission) published its report in 1987, it presented a new concept - sustainable development. The concept became one of the most successful approaches to be introduced in many years. Bangladesh Small and Cottage Industries Corporation faces huge problem encountered by lack of entrance, infrastructural and supply chain management problem. Informal market in Bangladesh is quite large as more than $87 \%$ employment is generated from this sector. Formal sector is gradually following contractionary employment opportunities.

BNF provides financial grants and need-based supports to develop their skills for stepping up such activities. With the support of BNF, Non-Governmental Organizations have been working at the root level countrywide and playing active role for sustainable development and making digital Bangladesh. Present Government of Bangladesh set vision 2021 and 2041 as a roadmap of development. To implement this initiative successfully, along with government, BNF's sincere involvement is imperative. Sustainable Development Goal (SDG) 1 calls for an end to poverty in all its manifestations by 2030 . It also aims to ensure social protection for the poor and vulnerable, increase access to basic services and support people harmed by climate-related extreme events and other economic, social and environmental shocks and disasters. Bangladesh Government wants to develop the country up to a level for which they have taken Vision 2021 and Vision 2041 with super goal to transform as upper middle income country and developed nation respectively.

To determine sustainability of BNF partners and Beneficiaries for socio-economic development -we used following core factors:

a) Has own land

b) Contribution in innovation and production

c) Fund collecting system

d) Regular source of income is required

Objectives are as follows: i) to assess whether small BNF grant can help to fulfill SDG 1

ii) to examine whether small BNF grant is helping for removing gender inequality i.e. SDG 5

iii) to provide some implications of the study.

BNF's grant is to help following programs for betterment of the rural economy of Bangladesh.

Table 1. Activities Done through BNF grant by POs.

\begin{tabular}{ll}
\hline S1. & Program \\
\hline 1. & Watsan \\
2. & Health Care \\
3. & Empowerment of Women \\
4. & Rehabilitation and amelioration of the condition of disabled persons \\
5. & Goat rearing, poultry, fatting of cows and vegetable farming \\
\hline 6. & Pre-Primary Education \\
7. & Training on tailoring handicrafts and needle work \\
\hline 8. & Integrated agricultural development \\
\hline etc and transfer of the latest farming technology, supply of
\end{tabular}

(Source: Survey) 


\section{Literature Review}

Zoysa (2012) commented that the Peoples' Sustainability Treaties acknowledge that sustainable development dialogues must take place beyond the time and space of the UNCSD2012 and the 'Green economy' and 'Institutional framework' themes of the Rio+20 Summit, and must transcend into a broader sustainability discourse. It is important to ensure that the voices and visions of all citizens are brought to the attention of local, national, regional and international policy makers and all stakeholders.

In Figure: 1 we have seen s process-based understanding of quality of life.

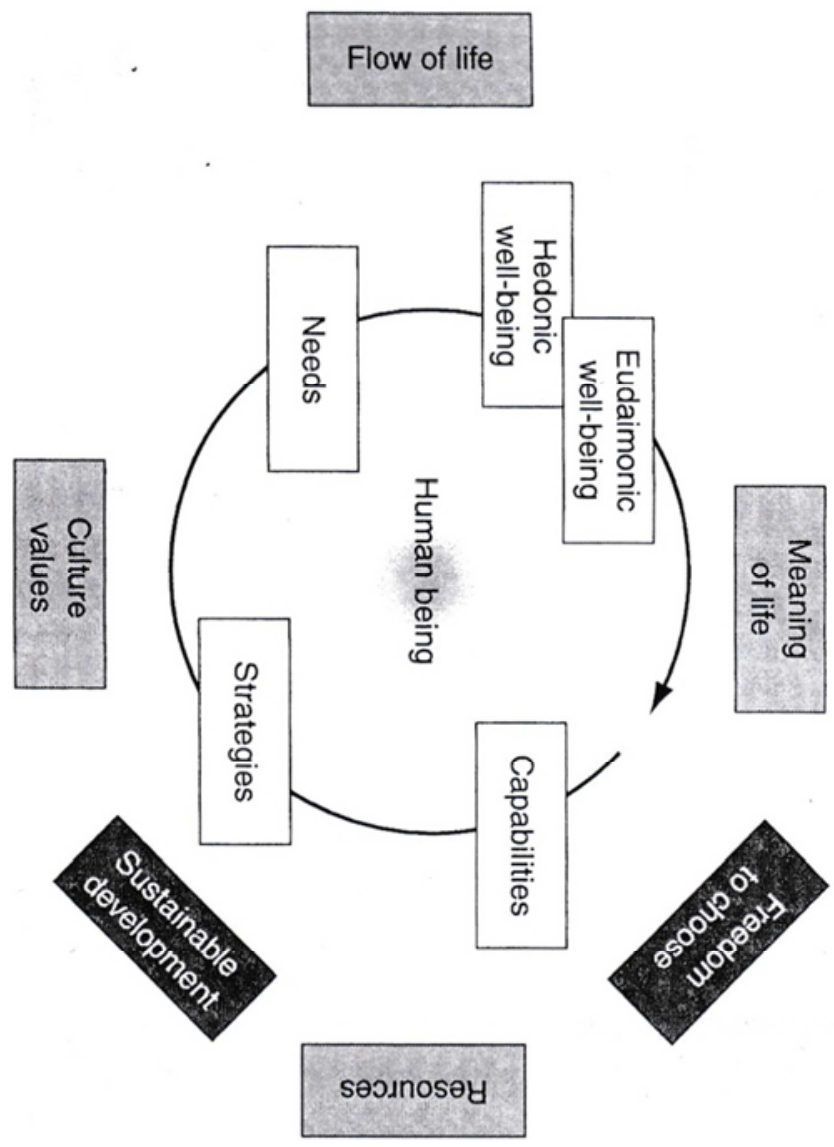

Figure 1. Process Based understanding of human being's quality of life.

Source: Rauschmayer et al. 2011) -Sustainable Development -Capabilities, needs \& well-being

SDG 1 refers to No Poverty - End poverty in all its forms everywhere:

a) Extreme poverty has been cut by more than half since 1990- however, more than 1 in 5 people live on less than $\$ 1.25$ a day

b) Poverty is more than lack of income or resources- it includes lack of basic services, such as education, hunger, social discrimination and exclusion, and lack of participation in decision making.

c) Gender inequality plays a large role in the perpetuation of poverty and its risks; they then face potentially of life-threatening risks from early pregnancy, and often lost hopes for an education and a better income.

d) Age groups are affected differently when struck with poverty; its most devastating effects are on children, to whom it poses a great threat. It affects their education, health, nutrition, and security. It also negatively affects the emotional and spiritual development of children through the environment it creates.

e) SDG -5 depicts Gender Equality - Achieve gender equality and empower all women and girls

f) Providing women and girls with equal access to education, health care, decent work, and representation in political and economic decision-making processes will fuel sustainable economies and benefit societies and humanity at large

g) While a record 143 countries guaranteed equality between men and women in their Constitutions by 2014, another 52 had not taken this step. In many nations, gender discrimination is still woven through legal and social norms

h) Though goal 5 is the gender equality stand-alone goalthe SDG's can only be successful if women are completely integrated into each and every goal.

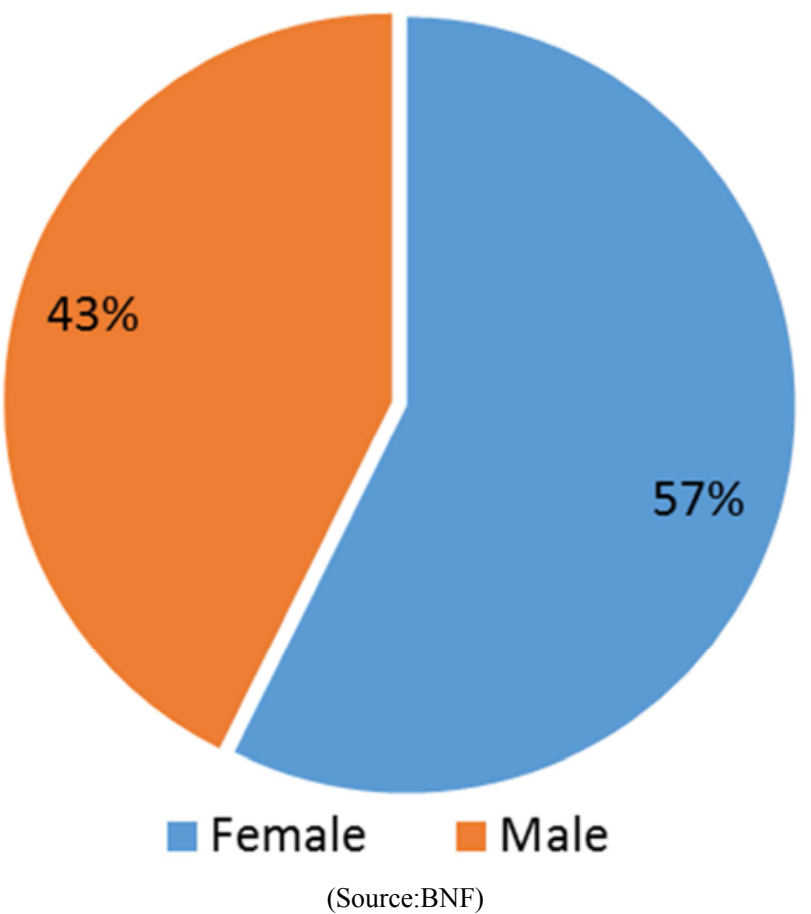

Figure 2. Shows percentage of Male and female beneficiaries of BNF Grant.

Ahmad (2016) described that given the notable success achieved in relation to the MDGs and also in the context of various other national issues in recent times, Bangladesh is poised for take -off on to a sustainable development pathway encompassing economic, social, and environmental -climate change aspects in an integrated fashion, keeping in focus the vision of progress of every citizen of the country without expectation towards the overarching goal of human dignity.

Ali (2016) depicted that the Sustainable Development 
Goals (SDGs) define global sustainable development priorities and aspirations for 2030 and seek to mobilize global efforts around a common set of goals and targets. The SDGs call for worldwide action among governments, business and Civil Society to end poverty and create a life of dignity and opportunity for all, within the boundaries of the planet which is based on 17 goals and 169 targets.

In recent times, roles of non-governmental organizations (NGOs) and government organizations are becoming debatable issues. These are also becoming subject matters for wider discussions and reviews in the developing country perspectives. Bangladesh is a member of the world's least developed countries, having increased population density, unemployment, illiteracy, child mortality, socio-communal unrest and many more. The country has also been facing massive challenges of feeding the rapidly increasing population or even to support their livelihood in a sustainable manner. However, the non-governmental organizations (NGOs) have been playing supportive roles with the government. In some cases, they are considered as more effective to get attached with the grass-root- level developmental initiatives. The roles and initiatives played by the NGOs in Bangladesh have been considered as having positive impacts on poverty alleviation among the rural poor population. In areas where the poverty situation remains intense, activities of the NGOs typically get more important. The target groups for these initiatives are mostly hard core poor who have very little access and opportunities for improving their living status and standards. Most of the rural peoples rarely own resources and capacities to fight against the poverty and to get employment. The very basic and important activities of the NGOs are to organize these peoples, to help to create awareness among them, inspiring them and through all of these efforts transforming.

UNESCO argued urgent action on eight key issues to ensure that development was sustainable, i.e. that it would satisfy 'the needs of the present without compromising the ability of future generations to meet their own needs'. These eight issues were ${ }^{1}$ :

- Population and Human Resources

- Industry

- Food Security

- Species and Ecosystems

- The Urban Challenge

- Managing the Commons

- Energy

- Conflict and Environmental Degradation

The three pillars of sustainability are a powerful tool for defining the complete sustainability problem at Chart: $1{ }^{2}$

\footnotetext{
${ }^{1}$ http://www.unesco.org/education/tlsf/mods/theme_a/mod02.html?panel=1\#top(vi ewed on $1^{\text {st }}$ July, 2017)

${ }^{2}$ http://www.thwink.org/sustain/glossary/ThreePillarsOfSustainability.htm(viewed on $1^{\text {st }}$ July, 2017)
}

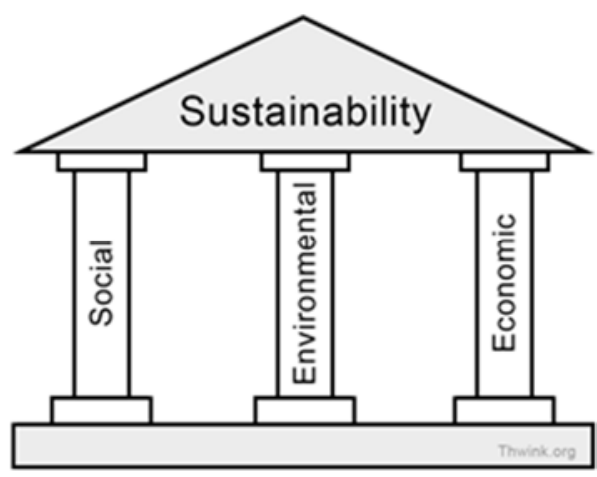

Chart 1. Three pillars of sustainability.

The study found literature gap where role of BNF grant for working to implement SDG is not previously studied. As BNF grant works to complement 9 goals out of 16 goals the study choose two goals effectiveness to measure. These goals are 1 and 5 as BNF grant is mostly used in this tenacity though any formal lunching.

\section{Methodology of the Study}

Following the typologies of research methodologies, this is often believed that the qualitative method is considered as traditional and this has been considered as having validity (Hair, et. al., 2011). Often regarded that the qualitative method is relatively well fit for studies that are based on human ideas with their activities and those tend to understand the existing psycho-sociological issues (Bryman and Bell, 2011). Out of 1120 NGOs who are currently working as BNF partner organizations we choose $23 \mathrm{NGO}$ for conducting survey of 12 districts out of who received $7^{\text {th }}$ installment fund of BNF. Two self-administered questionnaire was used in this study to collect the data i.e. one for NGOs and another for beneficiaries. The study has been conducted between 23 different participants from different 23 NGOs. Further from 23 NGOs, we received 526 beneficiaries' responses out of distributed 624 questionnaires based on another questionnaire. Among these 526 beneficiaries 344 are female beneficiaries and 182 respondents are male. Beneficiaries' data will collected by random sampling basis from 23 NGOs.

Besides this we also used secondary sources to understand whether BNF will sustain in the long run through using secondary sources. Sustainability of BNF will be judged by secondary sources.

Statistical calculation such as mean, standard deviation, binary logistic regression and Chi-square test was performed by SPSS computer programme. The descriptive and inferential statistics was also used accordingly in this research. Time period of the study was 15 May 2016 to $30^{\text {th }}$ June, 2017.

23 NGOs where the study which were selected as a sample out of 1120 POs, we received 526 beneficiaries' responses from 624 distributed questionnaires based on another questionnaire. Among these 526 beneficiaries 344 are female beneficiaries and 182 respondents are male. Beneficiaries' data will collected by random sampling basis from 23 NGOs. 
Table 2. Respondents of Beneficiaries.

\begin{tabular}{llll}
\hline Sl.no. & Name of the POs & Male Respondent & Female respondent \\
\hline 1. & ArthoSamajik o PoribeshUnnayan & 11 & 16 \\
2. & GaridohoNotun Para Nari & 8 & 15 \\
3. & Community Development & 9 & 14 \\
4. & Organization of Rural Economic Development and Rehabilitation & 8 & 12 \\
5. & DigantaSamajKallayanSomiti & 10 & 15 \\
6. & Centre on Socio- economic Development & 9 & 14 \\
7. & Organization for social Advancement & 8 & 21 \\
8. & Multipurpose Socio- economic Development Association & 7 & 15 \\
9. & Village Development Organization & 6 & 17 \\
10. & SrijoniSomajKollanSongstha & 5 & 12 \\
11. & Rupali Ideal DusthoMohilaKollanSongstha & 14 \\
12. & GrammoUnnoyanProchestha & 8 & 12 \\
13. & Gram UnnoyonDhara & 9 & 21 \\
14. & SOPAN & 7 & 14 \\
15. & Development for Society & 9 & 12 \\
16. & ManobSebaUnnoyonSonstha & 8 & 15 \\
17. & National Improvement Route & 7 & 16 \\
18. & Vumihin Unnoyan Sangstha & 5 & 12 \\
19. & Pabna Protishruti & 6 & 14 \\
20. & Environment \& Agricultural Development Association & 7 & 15 \\
21. & Nokshikatha & 8 & 17 \\
22. & SikhaSomaj Kollan Songstha & 10 & 17 \\
23. & Agriculture and Rural Advancement & 8 & 14 \\
\hline
\end{tabular}

(Source: BNF)

\section{Results}

\section{Contribution of BNF}

Organization working directly to remove poverty

Slightly above four-fifth (82.6\%) of the participants stated that their organizations were working directly to remove poverty.

Table 3. Organization working directly to remove poverty ( $n=23)$.

\begin{tabular}{lll}
\hline Variables & Frequency & Percentage \\
\hline Yes & 19 & 82.6 \\
No & 4 & 17.4 \\
Total & 23 & 100 \\
\hline
\end{tabular}

Source: Survey

\section{How income can be increased}

Regarding the participants opinion on how income will increase, majority $(21.7 \%)$ stated that income will increase by giving sewing machine training, followed by $17.4 \%$ those that mentioned giving education will be the solution to increase in income.

Table 4. How income can be increased $(n=23)$.

\begin{tabular}{lll}
\hline Variables & Frequency & Percentage \\
\hline Education & 13 & 57.7 \\
By given rickshaw \& vehicles to & 1 & 4.3 \\
strengthen rickshaw puller & 5 & 21.7 \\
Give sewing machine & 1 & 4.3 \\
Give computer education & 3 & 13.0 \\
All & 23 & 100 \\
Total & & \\
\hline
\end{tabular}

Source: Survey
Opinion regarding benefits of $N G O S$

Slightly above half $(52.2 \%)$ agree that male and female entrepreneur play multi role in economic development. $65.2 \%$ of the respondents were strongly agreed that their organization play role for discovery and productivity. Majority (69.6\%) of the respondents were strongly agreed that BNF's financing and capital formatting solve social problem. Slightly below threefourth $(73.9 \%)$ were strongly agreed that their organizations give right training/education to its employee. Majority (69.6\%) of the participants were strongly agreed that higher poverty rate hamper economic development.

Table 5. Opinion regarding benefits of $N G O$ s.

\begin{tabular}{lll}
\hline Variables & $\begin{array}{l}\text { Agree } \\
\mathbf{n}(\%)\end{array}$ & $\begin{array}{l}\text { Strongly Agree } \\
\mathbf{n}(\%)\end{array}$ \\
\hline $\begin{array}{l}\text { Male \& female entrepreneur play multi } \\
\text { role in Economic development } \\
\text { NGO play role for Discovery \& }\end{array}$ & $12(52.2)$ & $11(47.8)$ \\
$\begin{array}{l}\text { Productivity } \\
\text { BNF's Financing \& Capital formatting } \\
\text { solve social problem }\end{array}$ & $8(34.8)$ & $15(65.2)$ \\
$\begin{array}{l}\text { Organization give right Training/Education } \\
\text { Higher poverty rate hamper economic } \\
\text { development }\end{array}$ & $7(30.4)$ & $16(69.6)$ \\
\begin{tabular}{l} 
Total \\
\hline
\end{tabular} & $7(30.4)$ & $17(73.9)$ \\
\hline
\end{tabular}

Source: Survey

\section{Result of Beneficiaries of $\mathrm{NGO}$ s}

From the beneficiary point of view, a NGO will be sustainable if it provide sufficient fund to beneficiary (he/she does not need to take support from other sources) which inspire others to take support from the NGO, projects of the NGO help in social development and increase awareness to ensure primary education for all. 
Table 6. Association between factor influence over reducing poverty and Purpose of Loan.

\begin{tabular}{lllllll}
\hline \multicolumn{2}{l}{ Which factor influence for reducing poverty } & & & \\
\hline & poverty alleviation policy & Financial contributions & Social Facilities & Total & chi square \\
\hline \multirow{3}{*}{$\begin{array}{l}\text { Purpose } \\
\text { of Loan }\end{array}$} & Poultry & 15 & 95 & 29 & 139 \\
& Fishery & 14 & 13 & 7 & 34 & 113 \\
Total & Sanitation & 10 & 64 & 39 & 200 & $42.182^{* * *}$ \\
& Others & 18 & 144 & 38 & 486 \\
\hline
\end{tabular}

Source: Survey

Table 7. Chi square test for association.

\begin{tabular}{|c|c|c|c|c|c|}
\hline \multirow{3}{*}{ Variable } & \multirow{2}{*}{ Category } & \multicolumn{2}{|c|}{ Sustainable } & \multirow{2}{*}{ Total } & \multirow{3}{*}{ Chi Square } \\
\hline & & No & Yes & & \\
\hline & Yes & 68 & 313 & 381 & \\
\hline \multirow{5}{*}{$\begin{array}{l}\text { Do you aware of any poverty alleviation } \\
\text { program of govt. } \\
\text { Does your organization facilitate women } \\
\text { entrepreneurs }\end{array}$} & No & 10 & 382 & 392 & \multirow{2}{*}{$476.986^{* * *}$} \\
\hline & Yes & 134 & 0 & 134 & \\
\hline & No & 4 & 0 & 4 & \multirow{3}{*}{$10.84 * *$} \\
\hline & Yes & 138 & 382 & 520 & \\
\hline & No & 11 & 0 & 11 & \\
\hline \multirow{4}{*}{$\begin{array}{l}\text { Do you think the fund provided to the } \\
\text { partner organizations, has implemented } \\
\text { effectively }\end{array}$} & Yes & 133 & 382 & 515 & \multirow{4}{*}{$29.80 * * *$} \\
\hline & Neutral & 33 & 46 & 79 & \\
\hline & Agree & 1 & 7 & 8 & \\
\hline & Strongly Agree & 23 & 85 & 108 & \\
\hline \multirow{2}{*}{$\begin{array}{l}\text { Are your organization currently working } \\
\text { directly for poverty reduction }\end{array}$} & No & 8 & 0 & 8 & \multirow{2}{*}{$21.55^{* * *}$} \\
\hline & Yes & 136 & 382 & 518 & \\
\hline
\end{tabular}

Source: Survey

Significantly influential variables for sustainability of a NGO

Ultra poor is barrier for development is overall significant at 5\% level of significance. In case of fund transfer, it may be in installment at $1 \%$ level of significance.

Table 8. Comparison between beneficiaries to show the Goal 5 of SDG.

\begin{tabular}{llllllllll}
\hline \multirow{2}{*}{ Paired Differences } & \multirow{2}{*}{ Mean } & \multirow{2}{*}{ Std. Deviation } & \multirow{2}{*}{$\begin{array}{l}\text { Std. Error } \\
\text { Mean }\end{array}$} & & \multicolumn{2}{l}{$\mathbf{9 5 \% \text { Confidence Interval }}$} & & \multirow{2}{*}{ df } & \multirow{2}{*}{ Sig. (2-tailed) } \\
\hline Female - Male & 5.067 & 4.590 & 1.185 & 2.525 & Upper & 7.608 & 4.275 & 14 & 0.001 \\
\hline
\end{tabular}

Source: Survey

Females are getting more benefit from NGOs and the number of female beneficiaries is significantly higher than that of male.

From the 23 NGO's we received following comment on SDG-1 and 5.

Table 9. View on SDG-1 and 5 by the POs.

\begin{tabular}{lll}
\hline BNF grant is helping in the process of SDGs & Yes & No \\
\hline Observation & 17 & 6 \\
\hline
\end{tabular}

Source: Survey

Among 23 NGOs we got response of 526 beneficiaries where 344 are female beneficiaries and 182 respondents are male. Their comment is given below in SDG- 1 and 5.

Table 10. View on $S D G-1$ and 5 by the Beneficiaries.

\begin{tabular}{lll}
\hline BNF grant is helping in the process of SDGs & Yes & No \\
\hline Male & 168 & 14 \\
Women & 327 & 17 \\
\hline
\end{tabular}

Source: Survey

\section{Discussions}

Globally, support for NGOs is running high. Community support for campaigns such as Jubilee 2000 or Make Poverty History is evidence of this. The White Paper on the Australian Government's overseas aid programme released in 2006 is indicative of official aid agencies willingness to channel international development assistance through NGOs.

Without regular generating income sustainability of BNF will be in question. Further, BNF should take strategy to establish a training institute which is commercially viable and income generating.

Though their work is highly appreciable socially, economically and environmentally and maintenance good governance but to sustain in the long run they need to income generation.

Summary of the findings are given below in Table: 
Table 11. Summary of the findings.

\begin{tabular}{|c|c|c|c|}
\hline Specific Objectives & Hypothesis & Technique & Findings \\
\hline $\begin{array}{l}\text { To investigate whether BNF } \\
\text { fund helps to sustain individual } \\
\text { NGOs }\end{array}$ & $\begin{array}{l}\text { BNF fund helps to sustain } \\
\text { individual NGOs for socio- } \\
\text { economic development of the } \\
\text { country }\end{array}$ & $\begin{array}{l}\text { Association between sustainability of } \\
\text { NGO and activities based on BNF's } \\
\text { funding was examined using chi-square }\end{array}$ & $\begin{array}{l}\text { There is significant association } \\
\text { between BNF funding and individual } \\
\text { NGOs. }\end{array}$ \\
\hline $\begin{array}{l}\text { To determine NGOs role in } \\
\text { socio economic development }\end{array}$ & SDG & $\begin{array}{l}\text { SDG 1, for SDG } 5 \text {, comparison between } \\
\text { funding to male and female beneficiary's }\end{array}$ & $\begin{array}{l}\text { BNF POs are working to meet the } \\
\text { SDG } 5 \text {. }\end{array}$ \\
\hline $\begin{array}{l}\text { To investigate whether BNF } \\
\text { fund generates income of the } \\
\text { partner organization }\end{array}$ & $\begin{array}{l}\text { BNF fund generates income for } \\
\text { partner organizations }\end{array}$ & field visit & $\begin{array}{l}\text { In field visit, it is found that all the } \\
\text { BNF POs has income generating } \\
\text { activities including their beneficiaries } \\
\text { There is significant association }\end{array}$ \\
\hline $\begin{array}{l}\text { To find out impact on } \\
\text { beneficiaries }\end{array}$ & $\begin{array}{l}\text { BNF fund generates income for } \\
\text { beneficiary's sustainability }\end{array}$ & $\begin{array}{l}\text { Association between reducing poverty } \\
\text { and Purpose of Loan from BNF POs were } \\
\text { tested using chi square }\end{array}$ & $\begin{array}{l}\text { between reducing poverty and Purpose } \\
\text { of Loan from BNF POs. That is BNF } \\
\text { POs has impact on reducing poverty } \\
\text { which contribution social development }\end{array}$ \\
\hline
\end{tabular}

(Prepared by the authors)

The lead author Ali (2016) prepared following BNF Grant model and its impact on the economy.

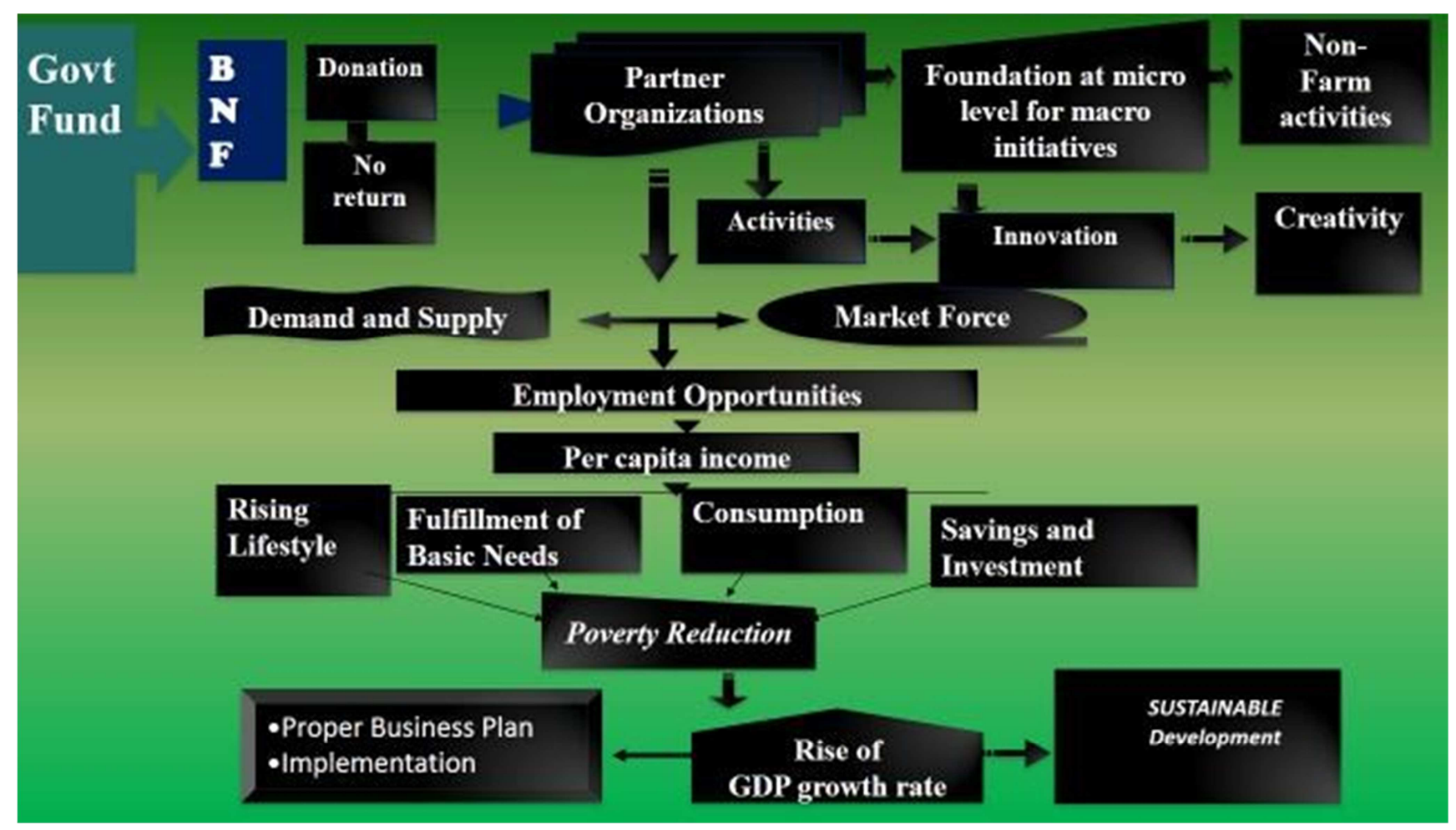

Source: Ali, 2016

Chart 2. BNF Grant model and its impact.

From aforesaid diagram we observed that how BNF grant is working to remove poverty. As a resultant factor socioeconomic development of the country is occurred through BNF Fund both its partner organizations and beneficiaries which needs sustainability in long run.

Moreover, Ali (2016) described that social Networking means social relations within networks on the basis of either human capital effects or the effects of organizational engagement through social capital, social business, social insurance, sustainable environment, efficiency and effectiveness and also use of social media. However, social media sometimes misused especially women and children.
Cyber crime should be strictly handled. Ali (2016) proposed study extensively tries to display an integral part regarding different dimensions of empowerment before involving in social networking and after involving in social capital, social along with business and social investment along with social intelligence, social education both formal and informal, social enterprises along with micro savings transformed to micro investment. Social intelligence is also one of the key components to readdress to come out from poverty. In Current century a greater role is being played by social media for which interpersonal connectivity in vital. Environmental scanning for doing the business is vital especially to ease the 
business process and local economies. Empowerment of people rises from decision making process when people do have purchasing power capability.

Technology, innovation and suitable regulations by the local level planning with local level law of transformed to nano investment.

Community banking will help to expedite the process of social networking and ultimately empowerment of people we have seen a model as concept developed by Ali (2016) based on aforesaid discussion in this section as Social Networking Model and empowerment of people through transformation of Micro savings to micro investment with the help of community banking. Post office, Palli Sanchya bank and Kormosangtha Bank, Ansar-VDP Bank may arrange community banking under separate govt. rules and regulations for a particular area where cost of transaction will be very low and small savings will be accumulated and transformed as social capital which can have positive impact on small investment. Creation of Employment both formal and informal sector with growth rate of GDP is very important. Ensuring equitable justice and social obligations can play vital role to implement SDGs.

\section{Concluding Remarks}

The government has established Bangladesh NGO Foundation (BNF) to support the NGOs, with a view to associate the Non-Governmental Organizations and mandated to take up socio- economic development activities and poverty alleviation initiatives through NGOs having previous experience of implementing similar programmes. From the binary logistic regression we observed that $67.2 \%$ NGOs who received funds are sustainable without BNF fund.

The findings of this study reveal that more than nine-tenth (91.3\%) of the NGOs are helping in developing women entrepreneur. It has been seen that there was significant association between NGOs role for discovery and productivity and giving the right training/education. The study observed that innovative business ideas among the poor people have been giving new dimension and varieties of product like arts and Handicrafts, folk songs, folk dance, Skills development programs for youth living with disabilities, farming, livestock, water and sanitation, Community Theater, nursery and botanical garden, multimedia and creativity etc., which is highly compatible and sustainable.

Social media does not still play positive role to encourage creative and artistic entrepreneurship as well as creating awareness. As such journalists/volunteers who are users of social media may take the initiatives to patronize nano and micro entrepreneurism through using social media. Moreover, in the rural area those who work individually with creative entrepreneurship do not get any sort of recognition or award by the govt. or private sector.

It is evident that creative entrepreneurs are being motivated long cultural heritage, independence war, and historical background. Bangladesh has long outstanding cultural heritage which can be utilized through optimum utilization of resources of the cultural environment for which creative entrepreneurs may get more patronization. Moreover, creative entrepreneurship can be used against the cultural participations and generating income as well as hate against militancy and terrorism. Sustainable development goal-5 is also applied gradually. This indicates that gender equality can be achieved.

Arvidsson and Niessen (2015) rightly observed that creativity is replaced by an embrace of markets and commerce as vehicles for self-expression. This also we observed in our analysis. Because creative entrepreneurs who are capable they not only improve their life style but retain for expansion of creative business which has positive impact in the market and they engage in business activities gradually in a larger scale and sustain in long run. This can only happen when a creative entrepreneur has competitive advantage among others and implement business formulation and strategy with efficiently and effectively. Creative business proliferation should be done in a greater extent so that social justice and income inequality can be removed.

Nano and micro entrepreneur should possess aptitude, attitude, skill, natural adoption capability to accept artistic entrepreneurship and networking especially women folk at rural areas. BNF is working as an angle investor though they are using government fund. In this study it has been seen that there was significant association between NGOs role for discovery and productivity and giving the right training for doing creative entrepreneurship at $10 \%$ level of significance. It has been observed that there is significant association between getting fund amount of installment and giving proper amount of donation at 5\% level of significance. There is no significant association between NGO helped directly to you for marketing purpose or arranging program and NGO helped for social networking. Through patronizing by BNF, those NGOs which are patronizing cultural activities to relate their products, services and events which act as creative design of meaningful practices and formation of the technique to generate income. Mapping different categories of opportunities to different types of nano and small providers Fostering skills inherent built among the creative entrepreneurs must be exposed. Private stimulus can occur through public stimulus through providing fund among the artistic entrepreneurs. Their innovative ideas need to get patronization by both public-private and foreign collaborative effort.

In the highly competitive situation only producing creative entrepreneurship is not sufficient but it should be accompanied by in search of excellence and attain competitive advantage through long run sustainability. Bangladesh Bureau of Statistics should have a database for fastest-growing companies in the nano and micro creative industries. Social value need to be characterized so that those who will be involved and put their input in the process of business must establish them in wealth based society. Market information should be collected by the artistic entrepreneurs so that they can improve their business process. Spillover 
effects occur as watchers get good moral messages and raises awareness against any wrong deed and some artistic entrepreneurs engaged in creation of awareness by community theater, folk song etc.

However, BNF needs extra fund for which foreign Bangladeshi expatriates can give their donation to them which can they use for increasing their social activities and patronizing creative entrepreneurship. In the free market economy, when role of the govt. is gradually decreasing and private sector is gaining potentialities but in a country like Bangladesh still govt. ought to play role of facilitator so that have notes get space to become not only self-employed but creating employment opportunities and generating income. As BNF needs fund so extra amount of fund can be generated by the well-wishers as they did not charge any interest or principal amount rather they give it as one time grant to partner organization. However, from our qualitative analysis and subjective judgment we observed that BNF fund has an impact on business process through the creative nano and micro enterprises. Rijnhout (viewed on $1^{\text {st }}$ October 2016) argued that to be most effective the post- - 2015 sustainable development framework must include a focus on marginalized communities and groups (rural communities, women, indigenous people) enabling their agency and access to justice and progressive good governance. It also needs to emphasize the equitable access to a fair share of natural resources while at the same time building climate resilient livelihoods through low carbon development pathways. To mitigate the SDG need Govt. of Bangladesh can distribute fund through BNF for evolving an innovative model for inclusive development; vital achievements for attaining the SDGs; nano and micro business as a device of community expansion, from side to side corporate social responsibility to remove hard core poverty from the society. Social welfare can be done and micro foundation for macro stability can be achieved. BNF fund is helping to create social justice and removing inequality, empowerment of community through ensuring development process, water and sanitation, purified water at costal area, skill enhancement. For the socioeconomic development of the country for which community banking is necessary where BNF can work as a catalyst role. Micro savings should be used as Micro investment through arranging community banking in the formal sector under structured rules and regulations.

In Bangladesh, a scanty amount of money can help poor folk to come out from the low level equilibrium trap for example through setting up and doing business on Prevention of Child marriage, dowry and oppression of women, goat rearing, arts and handicrafts, folk songs, folk dance, skills development programs for youth living with disabilities, nursery and botanical garden, community theater, street theater and multimedia and creativity for creating awareness for stopping child marriage, women trafficking, violence against child and women. Inspiring innovation at micro and small scale empowers pauper and marginalized people of the society to fight against poverty and improving their livelihood with adding value through creating corner stone. BNF grant also helps for developing health consciousness. Cheerfulness with marvelous elevation may be created if properly innovative entrepreneurship at small scale can be established. BNF also need to take a project to play as a financial intermediary to ensure community banking in Bangladesh under separate regulator. Current Chairman of BNF A F M Yeahyea Choudhury is a very dedicated person who is trying to up hold the image and contribution on domestic economic improvement as per the guideline of Ministry of Finance. Govt. should give more funding to BNF for implementing the SDGs achievable targets. BNF may have new activities for arranging start up grant for promoting new entreprenurs.

BNF can work in the following area in the line of SDG's and Seventh Five year plan to recommend to implement:

a) Food Security Program;

b) Health Nutrition Program

c) Improvement of quality enhancement of pre and post primary education level;

d) Special help for hill tract areas and Haor areas by POs.

e) The organization doesn't have Vision and Mission. Without vision and mission an organization cannot run. As such we are suggesting following draft vision and mission of the BNF which may be considered by the appropriate authority:

Proposed Vision of BNF:

Improvement of social development and enhancement of capacity building of the local NGOs \& CBOs along with implementing some goals of sustainable development goals.

Proposed Mission of BNF:

BNF as a non-profit organization will strive to enhance capability of the poor and ultra-poor of the country and promoting capacity building among the partner organizations. The policy planning and action programming center on human beings and focus on socio-economic development and environmental protection.

Super Goal:

BNF may take focused based objectives to establish community banking through arranging micro savings into micro investment and also arranging micro insurances.

The support and services provided relate to education, goat rearing, WATSAN, IGA, women empowerment, social forestry, tree plantation and environmental development, Training on human rights, Development of low caste Hindu, indigenous and tribal families, Food and Nutrition, HIV/AIDS etc. ENRICH project of PKSF may be linked with other organizations to develop the economy of the country.

\section{Implications:}

a) BNF partner organizations must try to have better competitive advantages and mitigate social economical-legal need so that grand utility curve can be tangent with social indifference curve.

b) BNF may set up a business incubator which can organize training, counseling and financial support to hopeful entrepreneurs in the performing sustain long run.

c) For more generation of fund to establish and encourage for creative entrepreneurship so that poor downtrodden 
people can come out with innovative business process through financial inclusion process.

d) Creative enterprises should get patronize by NGOs and buyers through giving Fair Price.

e) For buyers public-private -foreign collaboration is required for both domestic and international trade and BNF can take the help of Mosques, temples, and churches to engage more rural people for converting innovative business process and coming out from poverty.

f) Foreign expatriates can give their donations directly at the bank account of BNF for which necessary steps should be required and this fund may give more strength to give access to the nano and micro enterprises of the poor people.

g) Product, service and event development may occur so that input can be processed as output in the creative industry.

h) Even in the rural area those who are involved in the process of nano and micro entrepreneurship must think about a business model comprising operational efficiency and cost effectiveness. Without profit no one should engage in any sort of entrepreneurship.

i) Training institute of BNF must be commercially viable so that it can generate more nano and micro entrepreneurs. BNF may sign a MOU with Dhaka School of Economics for organizing their training programs for partner organizations at the School until they have own training institute.

j) BNF may sign a MOU with PKSF for jointly working on Climate change of the country.

k) A strategic business plan and implementation regarding the creation of a niche in the artistic/creative industry with innovation as per the demand of the market in which BNF can play more catalyst role.

1) Form domestic and global joint ventures which may encourage visibility, promotion and network so that creative entrepreneurs can work with more zeal, enthusiasm, aptitude and skill for fulfilling SDG 1 and 5 in the country successfully.

m) Sustainable development goals can be achieved through holistic approach. In this process BNF can be included by the govt.

n) Salary structure should be justified so that personnel of BNF can be motivated to work.

o) Organoram of the BNF needs to be readjusted and expanded as they are trying to take more challenges for implementing SDGs at local level.

p) BNF needs special govt. fund to act as a facilitator of the some goals of SDG implementation process.

q) BNF may take imitative to start with community banking and social network for channeling micro savings into micro investment.

r) BNF may jointly work with PKSF in the process of implementation of ENRICH program.

Future Research:

In future, study may be done whether BNF can be sustained without further govt. fund. Effectiveness and efficiency of monitoring process of BNF fund along with disbursement of fund through installment may be quantitatively measured. A separate study may be undertaken if BNF take marketing strategies of the beneficiaries whether it will be effective one or not. Moreover, another study can be undertaken to find out how socio -economic development works due to sustainability of BNF's grant fund among the Partner organizations and their beneficiaries. The theory which was developed by Muhammad Mahboob Ali on Social networking, community banking and empowerment of people may be tested in different areas of the country by various researchers to give a structural formation, costbenefit analysis, shadow pricing, validation and reliability of the theory in the real life scenario both global and domestic perspectives.

\section{References}

[1] Abed, F. H., \& Chowdhury, A. M. R. (1989). The role of NGOs in international health. In M. Reich \& E. Marui (Eds.), International cooperation in health. Dover, Mass.: Auburn House Publishing Company.

[2] Ahmad, Qazi Kholiquzzaman (2016). Sustainable development and all that, Pathak Shmabesh Bangladesh, pp. 215-227.

[3] Ahmed, Momtaz Uddin (2015).”Entrepreneurship and economic Development: A Discourse on selected conceptual issues", Daffodil international University Journal of Business and Economics, Vol. 9, No. 1, pp. 187-193; June.

[4] Ahmad, M. M. (2001). The State, Laws and NonGovernmental Organisations (NGOs) in Bangladesh. International Journal of Not-for-Profit Law, 3(3).

[5] Ali, Muhammad Mahboob (2016). "Social networking, community banking and empowerment of people: alternative framework for welfare of human being", presented at the 14 th Asian business research conference on 30 - 31 December, 2016, BIAM foundation, Dhaka, Bangladesh organized by world business institute, Australia.

[6] Ali, Muhammad Mahboob (2017). Socio-Economic Development of Bangladesh: Sustainability of BNF's partner organizations and Beneficiaries, MTC Global, India, pp. 17-29.

[7] Anon. (2003, 28/02/2003). Federation of NGOs in Bangladesh launched. Holiday (Internet Edition). Retrieved 17/03/2006,

http://www.weeklyholiday.net/28/02/203/met.html 16

[8] Arvidsson, Adam and Niessen, Bertram (2015). "Creative mass. Consumption, creativity and innovation on Bangkok's fashion markets", Consumption, Markets \& Culture. April, Vol. 18 Issue 2, pp.111-132.

[9] AusAID. (2006). Australian Aid: Promoting Growth and Stability. Canberra: Australian Government.

[10] Begum, A. (2004). NGO Activities in Rural Bangladesh: Beneficiary perceptions about the impacts. In S. Hasan \& M. Lyons (Eds.), Social Capital in Asian Sustainable Development Management (pp. 101-112). Hauppauge, NY: Nova Science Publishers Inc. 
[11] Blair, H. (2005). Civil society and pro poor initiatives in rural Bangladesh: finding a workable strategy. World Development, 33(6), 921-936.

[12] BRAC. (1983). The Net: Power structure in ten villages. Dhaka: Bangladesh Rural Advancement Committee (BRAC).

[13] BRAC. (2015). BRAC Annual Report. Dhaka: BRAC.

[14] Devine, Joseph (2003). "The Paradox of Sustainability: Reflections on NGOs in Bangladesh", The ANNALS of the American Academy of Political and Social Science, November vol. 590 no. $1227-242$.

[15] Fernando, J. L., \& Devine, J. (2003). The paradox of sustainability: Reflections on NGOs in Bangladesh. Annals of the American Academy of Political and Social Science, 590(2), 227-242.

[16] Gono Unnayan Prochesta. (1999). Gono Unnayan Prochesta Bangladesh. ESCAP Virtual Conference Retrieved 8/05/2006, from http://unescap.org/drpad/vc/conference/ex_56_hup.htm

[17] Government of Bangladesh. (2005). Poverty Reduction Strategy Paper: Unlocking the potential: National Strategy for accelerated poverty reduction. Dhaka: General Economics Division, Planning Commission.

[18] Haq, E. (Ed.). (1979). Meet Bangladesh (First ed.). Dhaka: Department of Films and Publications.

[19] Hasan, S. (1993). Voluntarism and rural development in Bangladesh. Asian Journal of Public Administration, 15(1), 82101.

[20] Hashemi, S. M., \& Morshed, L. (1997). Grameen Bank: A case study. In G. D. Wood \& I. Sharif (Eds.), Who needs credit? Poverty and finance in Bangladesh (pp. 217-227). Dhaka: University Press.
[21] Mahmood, K. (Ed.). (1987). Meet Bangladesh (Third ed.) Dhaka: Department of Films and Publications.

[22] Maloney, C., \& Ahmed, A. B. S. (1988). Rural savings and credit in Bangladesh. Dhaka: University Press.

[23] Mir, Monir and Bala, Swapan Kumar (2014). NGO Accountability in Bangladesh: Two Contrasting Cases, International Society for Third-Sector Research and The Johns Hopkins University.

[24] Netherlands Ministry of Foreign Affairs. (1998). Evaluation of Netherlands funded NGOs in Bangladesh, 1972-1996. The Hague

[25] Rauschmayer, Felix et al. (2011). Sustainable developmentCapabilities, needs and well-being, Routledge, Canada, pp. 112.

[26] Stiles, K. (2002). International Support for NGOs in Bangladesh: Some Unintended Consequences. World Development, 30(5), 835-846.

[27] White, S. C. (1999). NGOs, Civil Society, and the State in Bangladesh: The politics of representing the poor. Development and Change, 30, 307-326.

[28] Wood, G. D., \& Sharif, I. (Eds.). (1997). Who needs credit? Poverty and finance in Bangladesh. Dhaka: University Press.

[29] World Bank. (2006). The economics and governance of Non Governmental Organizations (NGOs) in Bangladesh (No. 11). Dhaka: World Bank.

[30] Zoysa, Uchita de (2012). Peoples' Sustainability Treaties for Rio +20 , United Nations Environment Programme, PERSPECTIVES, February, Issue: 3, pp. 1-6. 